\title{
International aid and development: hearing multilingualism, learning from intercultural encounters in the history of OxfamGB
}

Article

Published Version

Creative Commons: Attribution 4.0 (CC-BY)

Open Access

Footitt, H. (2017) International aid and development: hearing multilingualism, learning from intercultural encounters in the history of OxfamGB. Language and Intercultural

Communication, 17 (4). ISSN 1470-8477 doi:

https://doi.org/10.1080/14708477.2017.1368207 Available at https://centaur.reading.ac.uk/72310/

It is advisable to refer to the publisher's version if you intend to cite from the work. See Guidance on citing.

To link to this article DOI: http://dx.doi.org/10.1080/14708477.2017.1368207

Publisher: Taylor \& Francis

All outputs in CentAUR are protected by Intellectual Property Rights law, including copyright law. Copyright and IPR is retained by the creators or other copyright holders. Terms and conditions for use of this material are defined in the End User Agreement. 


\section{CentAUR}

Central Archive at the University of Reading

Reading's research outputs online 


\section{International aid and development: hearing multilingualism, learning from intercultural encounters in the history of OxfamGB}

\section{Hilary Footitt}

To cite this article: Hilary Footitt (2017) International aid and development: hearing multilingualism, learning from intercultural encounters in the history of OxfamGB, Language and Intercultural Communication, 17:4, 518-533, DOI: 10.1080/14708477.2017.1368207

To link to this article: https://doi.org/10.1080/14708477.2017.1368207

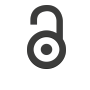

(c) 2017 The Author(s). Published by Informa

UK Limited, trading as Taylor \& Francis Group

\section{Published online: 28 Aug 2017.}

Submit your article to this journal

Џ Article views: 99

Q View related articles $\square$

View Crossmark data $₫$ 


\title{
International aid and development: hearing multilingualism, learning from intercultural encounters in the history of OxfamGB
}

\author{
Hilary Footitt
}

Department of Modern Languages and European Studies, University of Reading, Reading, UK

\begin{abstract}
This article explores the context of intercultural relations in the field of international aid and development. Examining the activities of a large UK-based transnational NGO (OxfamGB) through a detailed reading of its own 60-year-long archived story, the article seeks to reimagine the 'contact zones' of aid and development as multilingual and intercultural. In doing so, it offers an empirically grounded account of intercultural relations within a transnational institution, and seeks both to provide additional understandings of the politico-social power dynamics which frame such intercultural fields, and to contribute to current critiques of Western donor 'upward accountability' in development with its focus on the contractual, the standard and the quantifiable.
\end{abstract}

Este artículo examina el contexto de las relaciones interculturales en el campo de la ayuda y el desarrollo internacionales. Estudiando las actividades de una importante ONG internacional ubicada en el Reino Unido (OxfamGB) a través de su historia de sesenta años conservada en sus archivos, el artículo trata de imaginar las 'contact zones' de la ayuda y el desarrollo internacional como espacios multilingües e interculturales. El propósito es el presentar un estudio empírico de las relaciones interculturales dentro de una institución internacional. De este modo se presenta un estudio que busca tanto ampliar la comprensión de las dinámicas de poder socio-cultural que enmarcan las mencionadas relaciones interculturales, como apoyar a las críticas contra las herramientas de 'upward accountability' que priorizan lo contractual, la estandarización, y lo quantificable.

\section{KEYWORDS}

International aid;

development; multilingualism; contact zones; transnational; sustainable development goals (SDGs)

\section{Introduction}

The United Nations Sustainable Development Goals (SDGs) seek to transcend old 'NorthSouth' paradigms by making the vital link between the reduction of global inequality and an 'enhanced representation and voice for developing countries' (SDG 10). Civil society organisations involved in international aid and development are increasingly reflecting on their own place in this shifting world order (Bond, 2015), and on ways of 'Doing 
Development Differently', focusing on 'local problems that are debated, defined and refined by local people' (DDD, 2014). For large international NGOs based in the UK, embracing the multilingual and intercultural affordances of this new situation is vital but difficult, implying a form of learning which may potentially require, 'a searching and doubtless painful examination of our own internal patterns of power and prejudice' (Green, 2015).

In this discussion of NGO institutional learning, I hope to be contributing to three ongoing debates. In intercultural studies, the research will offer an empirically grounded account of intercultural relations within an institutional learning setting which has so far been little explored - a transnational organisation (a large UK-based international NGO) which has a long history of aid and development interventions. Secondly, the article aims to provide additional understanding of the complexities around framings of the intercultural field, the politico-social and spatial interactions and diffuse power dynamics which create specific contexts for intercultural learning and mutual understanding. Finally, reimagining the 'contact zones' of aid and development as multilingual and intercultural will stand as a contribution to current debates in Development Studies critiquing the politics of evidence, and challenging the paradigm of Western donor 'upward accountability' with its overwhelming focus on the contractual, the standard and the quantifiable (Banks, Hulme, \& Edwards, 2015).

In the twenty-first century, the role of aid and development agencies is crucial firstly in providing immediate on-the-ground support to those affected by emergencies, secondly in working with communities to develop life chances and opportunities, and thirdly in advocating for policy change with governments and international institutions. The point at which the interests of scholars in intercultural communication meet with those of aid and development studies is arguably in their shared interrogation of the nature of context, space, and location. Alison Phipps (2014) maintained that the strongly normative flavour of much work on intercultural dialogue had been influenced by the educational settings - schools, universities - often chosen for empirical research. Prue Holmes warned scholars of intercultural communication to be, 'ever mindful of context and power' (2014, p. 6). Ulrike Najar (2016), following the lead of postmodern geographers like Doreen Massey (2005), posited an 'intercultural field' seen as the contingent product of relationality, in a permanent state of construction and change. From International Relations, Lisa Smirl has urged development scholars and practitioners to focus on the imaginative geographies of their 'fields': 'Turning the frame of analysis back upon the spaces and practices of the international aid community and the material and cultural aspects of the delivery of aid' (2015, p. 13).

The spaces of international aid and development are particularly interesting in any debate on language, context and power. NGOs working in this field are, as Dijkzeul argues, 'transnational organisations pur sang ... they usually operate in various localities ... in a decentralised manner through their activities ... in, above, and between the traditional "container spaces" of national societies' (2008, p. 80). Pries suggests that the study of such transnational agencies should include 'border crossing, pluri-local, societal spaces' as units of reference, concentrate on 'biographies, families, organisations, institutions, identity' as units of analysis, and use 'individuals, households, rituals, flows of goods' (2008, p. 7) as units of measurement. This fundamentally human and relational understanding of transnationalism carries with it the implication that the institution itself will be affected and changed by its encounters: 'It does not assume ... that everything 
originates and flows from the west and north but that the direction, intensity, and effects of global cultural flows is an empirical question' (Khagram \& Levitt, 2008, p. 33). Thus, for example, Dijkzeul's study of Malteser International's humanitarian work in the Democratic Republic of Congo examined how the diversity of cross-border operations was reflected in management strategy and organisational structure, and how the transfer of ideas actually took place within an integrated network, focusing on the role of personal contacts, socialisation and learning within the NGO (2008).

A series of recent NGO listening studies attests to the seriousness with which aid and development agencies approach the need to hear the voices of the 'beneficiaries' of their actions. Thus, Médecins Sans Frontières, in the wake of its experiences in the Democratic Republic of Congo in 2005, undertook an In the Eyes of the Others survey to try and understand how the organisation was actually perceived by those within the country (Abu-Sada, 2012). The International Committee of the Red Cross (ICRC) marked its 150th anniversary with an extensive listening project (ICRC, 2009) which recorded the words of victims of war and conflict - first responders (health workers arriving in the early stages of an emergency), mine victims, victims of rape and sexual violence, and internally displaced populations. By far the largest of these feedback exercises was the aptly named Time to listen: Hearing people on the receiving end of international aid (Anderson, Brown, \& Jean, 2012) which involved 400 teams in over 20 countries, listening to 6000 people.

There is, however, a sense in which this ongoing intercultural listening and learning of NGOs has often been framed within a relatively short time-scale, through after-action reviews or evaluations related to specific aid programmes aiming at incremental improvements. As Davey and Scriven argue, there may be much for NGOs to learn by challenging such a presentist perspective:

The past, written into history and recalled as memory, is an essential part of identity, whether individual or organisational. It offers a way of structuring and explaining the values we hold ... history shapes how we think, not just what we think. (2015, p. 117)

This article deliberately takes as its research focus a longer time frame of aid and development as seen in the activities of one particular NGO, OxfamGB. Founded in 1942, Oxfam is one of the largest UK-based NGOs, currently active in 48 countries, with more than 1000 local partners. Importantly, it is a highly self-reflexive organisation which has always operated as a leader in international aid and development, stimulating new research and innovation. Oxfam is strongly aware of the importance of its own history, and in 2013, deposited the vast archive of its institutional story - spanning the years since the Second World War up until the early 2000s - in the Bodleian Library, Oxford. It is from this only recently available collection that my current research is drawn. By looking at policy and management discussions, at considerations of applications for funding, and at detailed reports from the field on development activities, particularly in Africa and Latin America, I am aiming to discover how the international spaces of Oxfam's encounters were perceived, and how they entered into and changed its institutional learning.

This endeavour, exploring the languages histories of Oxfam, reimagines the spaces of aid and development as multilingual and intercultural, as what Mary-Louise Pratt describes as 'contact zones': 'the space and time where subjects previously separated by geography and history are co-present, the point at which their trajectories now intersect' 
(2008, p. 8). Such a reimagining shifts attention towards the interactive, the relational, seeing how Pratt's, 'co-presence, interaction, interlocking understandings and practices, ... often within radically asymmetrical relations of power' actually affect the aid agencies themselves, how Oxfam learned from the intercultural 'contact zones' of intervention in which it worked throughout the world. In this refocusing, 'translation' in the sense that Ricoeur used it is key in the aid and development dynamic, positing a broad ontology of exchange as a paradigm for transnational relations. 'Translation' for Ricoeur is not just a means of communication, but also, and above all, an ethic of exchange, one which replaces any utopic illusion of perfection - a 'perfect translation' - with a 'desire to translate' or understand, to engage with the other and, through this engagement, to obtain a broader understanding of oneself - 'the patient, hospitable work' of translation (Taylor, 2010, p. 8). Ricoeur calls this process 'linguistic hospitality': 'Linguistic hospitality ... is the act of inhabiting the word of the Other paralleled by the act of receiving the word of the Other into one's own home, one's own dwelling' (2006, pp. 19-20). The notion of translation as an activist performance situating intercultural openness within a process of mutual exchange potentially moves the development debate on $\mathrm{NGO}$ /'beneficiary' interactions away from one-sided NGO listening, or 'beneficiary' feedback, towards a paradigm of conversation, transnational exchange, and narrative plurality.

\section{Hearing multilingualism}

Whilst there has been some research in aid and development which takes as its starting point the fact of multilingualism - Clinton Robinson's early work on language use in rural development in Africa (1996), Djités study of the sociolinguistics of development in Africa (2008), and Kobus Marais' more recent book on translation theory and development (2014) - little attention has been paid to how Western interveners themselves become aware of the language complexities of the areas in which they work, and how, as institutions, they begin to hear multilingualism.

At the outset, the organisational model adopted by aid and development agencies provides a basic geography of distance from/closeness to the 'contact zones' of foreign encounter, suggesting the extent to which an apprehension of language diversity on the ground is potentially mediated or experienced first hand. To take one extreme, Christian Aid, from its inception in the immediate postwar until today, has worked vicariously, never directing its own projects, but rather using the services of intermediary organisations. Through much of the twentieth century, it relied on the World Council of Churches (WCC) to pre-select programmes to be supported, and to provide an infrastructure of feasibility studies and feedback reports. Whilst Christian Aid staff themselves often had knowledge and experience of key areas, it was the WCC which advised on the suitability of zones of engagement. In Christian Aid's terms, the existence of an international intermediary body enabled them to administer an overseas programme with the minimum of staff, and without needing direct institutional contact with the countries concerned. ${ }^{1}$

In comparison, OxfamGB, after initially operating in a similar way in liberated Europe, through intermediary aid agencies like the Friends Service Council or the British Red Cross, began in the early 1960s to develop a very different organisational model, directing its own projects on the ground within the countries concerned (Whitaker, 1983), and thus bringing NGO staff directly into the 'contact zones'. By 1967, Oxfam was employing ten 
Field Directors based outside the UK - four in Africa, two in West Asia, one in the Far East, two in Latin America, and one in the Mediterranean/North Africa. How were these workers prepared for one-to-one encounters in the 'contact zones'? Tasked with building a rapport with groups in the locality, assessing project applications, and making recommendations to Oxfam, they were expected to have imagination, plenty of common sense, a practical turn of mind'. ${ }^{2}$ Crucially, their recruitment profile stressed the need for experience of the regions, with foreign language competence identified as 'desirable' or 'important': 'Knowledge of Arabic desirable or prior language ability' (Egypt); 'knowledge of French important' (Kampuchea); 'language facility' (Somali/ Arabic); 'desirable' (Somali). ${ }^{3}$ In the early conditions of service for overseas staff, there was an assumption that the agency would contribute to language learning costs. ${ }^{4}$ As Oxfam expanded its headquarters staff in Oxford, it was assumed that they too would have appropriate country and linguistic experience: 'They should have visited Latin America ... they must have good written and spoken Spanish and/or Portuguese. ${ }^{5}$ On the whole, expectations around staff linguistic competence tended to relate to European languages, a fact indeed that contributed to internal debates in 1990 about whether a 'Eurocentric view of the world' might be making it difficult for Oxfam to listen to what partners were actually saying. ${ }^{6}$

Within policy debates, decision-making and field reports, explicit awareness of the multilingualism of the areas in which Field Directors worked was variable. In Latin America, for example, as soon as Oxfam became active in the early 1970s, staff were reporting back on the linguistic practices of the sierras, and the relatively low respect in which they were held by central governments: 'The majority of Indians in the sierras speak Quechua or Aymara, yet with the exception of Peru ... all have seen Spanish as the only language of the school system ... schools are conducted in a foreign language'; 'unless the Indians are taught in their own language and are helped to build up and preserve some tribal pride and cohesion there is no hope for them'. It was clear to Oxfam staff on the ground that the issue of language was closely related to that of power and control: 'Levels of organisation vary, and is made difficult by mestizo models of organisation prevailing amongst a population that was largely nomadic. ${ }^{8}$

By comparison, in dealings with anglophone ex-colonial Africa, an overt awareness of the multilingualism of the continent appeared much later in reports and policy discussions at headquarters. Thus, it was not until the mid-1990s, when Oxfam started sponsoring a project in Malawi led by a local development expert that the country's linguistic diversity entered visibly into the agency's formal debates: 'Lomure, Manglanga and Yao are mutually unintelligible languages, reflecting their different geographical origins though all groups speak Chichewa as a lingua franca.'

In the second place, an openness to hearing multilingualism also depended on the ways in which Oxfam perceived the local interlocutors with whom they dealt, and on their understanding of specific political and social dynamics in the area concerned. In Malawi, for example, the long-running and repressive regime of Dr Hastings Banda was one with which Oxfam refused to negotiate, which meant that its interlocutors effectively became other NGOs. Some of these, like the Malawi Council for Social Welfare, were split generationally between older Malawians wanting Oxfam to support government efforts, and younger members calling on them to engage in policy advocacy and change. Given the difficulties of working directly in Malawi, Oxfam tended to listen to the experiences 
of other international NGOs in the country. ${ }^{10}$ In comparison, in Peru in the 1980s, Oxfam found itself operating, 'between two fires', on the one hand resisting government pressure to take over and control all aid programmes, and on the other, supporting local groups who were trying to survive in the conflict gripping the country. By the late 1980s, violence had escalated to such an extent that the state had de facto retreated to urban areas, leaving major parts of the sierras in the hands of the rebel Sendero Luminoso. In this situation, Oxfam concentrated on, 'imaginative and secure ways of changing the form of work to meet the growing problems of violence', in effect keeping as low a profile as possible in order to provide aid to those in need. ${ }^{11}$

Increasingly, of course, a major actor in the 'contact zones' was the institutional/government donor who sponsored a growing range of activity. Inevitably, the language of the donor, rather than the fact of local multilingualisms, became a critical shaper of linguistic perceptions. The UK Government had long-standing and largely unquestioned assumptions about the importance of the English language in aid and development. The linkage between the teaching of English and modernisation and development was one which was repeated mantra-like by British policy-makers over the years, despite the fact that there was little evidence that such a link actually existed (Coleman, 2010; Djité, 1993). ${ }^{12}$ The UK Government tended to frame English as a global language, an international lingua franca, not exclusively associated with a particular country or culture, but one which represented an admission to a modern, advanced way of life. This assumption underpinned much of British-funded development activities over the years, implicitly positioning English as a means of enabling access to the latest innovations in science and technology, and therefore as being key for transitioning from predominantly rural economies to a more advanced society. Indigenous languages were traditionally regarded (implicitly as well as explicitly) as an obstacle to progress. In British Government donor circles, there was an accepted equivalence between effective aid delivery and monolingualism.

Most importantly, the key role of the government as donor, and the concomitant expectations that agencies would have to be publicly responsible for taxpayers' money, tended to contribute to a meta-discourse of accountability, also expressed in English, which added to an already anglo-dominated lexicon of aid and development whose key concepts, buzzwords (Cornwall \& Eade, 2010) - 'partnership', 'advocacy', 'capacity building' - when taken into other languages, generally appeared as loan words. Historically, although Oxfam had been concerned to ensure that the role of government and large institutional donors should not inhibit its working style and choice of projects, ${ }^{13}$ the influence of this anglophone donor positionality now became evident in its own practices as well as those of other major aid agencies: Dichter (1999), for example, described ActionAid's work in the 1990 s as having equated the need for accountability and reporting with a growth in central systems and bureaucracy. An examination of Oxfam's pioneering guidance for its Field Directors from 1985 onwards showed an increasing tendency to standardise and to use contemporary development lexis. Thus, the 1985 Field Directors' Handbook provided the previously autonomous Field Directors with clear directions on target audiences, and a checklist of questions in relation to each. The long section on 'Communication' defined the activity as, 'the interaction between those promoting change and the people with whom they work', within an apparently alinguistic frame, describing the function, channels, and strategies of communication in ways uninflected by distinct languages or 
cultures (Prat \& Boyden, 1985). By 1995, the Handbook was offering reframings which critiqued previous participation shibboleths, and proposed a new set of ethnographic tools derived from Participatory Rural Appraisal to encourage more meaningful contact. The vocabulary (together with the corresponding acronyms) - Capacities and Vulnerabilities Analysis, Gender Framework Analysis, Environmental Impact Assessment, Logical Framework Analysis, and Cost-effectiveness Analysis - equipped Oxfam workers with a structure implicitly assumed to be valid for any community or country. Whilst this might clearly support the transfer of good development practice from one part of the world to another, diversity and particularity, the specific cultural contours of the regions, the multilingualism of the areas, tended to recede (Oxfam Handbook, 1995).

As accountability to institutional donors became ever more pressing, aid agencies sought to assemble proof of their good stewardship of funding through an evidence base of cost effectiveness and value for money. To enable this to happen, NGOs like Oxfam began to express their relationships with communities on the ground in terms of quasi legal exchanges: 'contracts with counterparts which state the rights and obligations of Oxfam and recipients of funds, including agreement on aims, objectives, activities and indicators of impact'. ${ }^{14}$ What would formally be exchanged in these encounters would be evidence of contract fulfilment, demonstrable results in the form of written (and if possible quantifiable) data. Oxfam Evaluation Officers called for a systematised transfer of data - records of informal discussions, details of meetings logged through diaries. ${ }^{15}$ By 1995, this had been reformulated into a number of listening indicators to measure participation: 'How closely and how well programmes listen to those they are trying to support and thereby increase their "porosity" to feedback? To what degree do programmes "triangulate" information ... ?" ${ }^{16}$ Although the expectation was that this higher standard of reporting would be positive in requiring, 'a deeper understanding of the local situation', it inevitably framed the Oxfam/local community relationship as one which was in part extractive and monolingual, with information required by the NGO named in English and taken out of the community for the purposes of evaluation. ${ }^{17}$ Although deriving its authority from Western models, the approach tended to be presented as objective and neutral, a kind of universal aid and development language.

Some in Oxfam in the early 1990s argued strongly that these requirements for stricter reporting might produce programmes which were considerably less effective. Thus, for example, a health improvement initiative led by local elite trained medics could be chosen for support by Oxfam on the grounds that reporting from these groups would be more professional than that from partners drawn from community witch doctors and GPs, although the latter partnership might actually be the one which would lead to concrete successes at a local level. From this perspective, the development lexicon seemed considerably less open to the experiences of others than Oxfam's previous guiding principle, 'to have and to be more': "Being more" captures the notion of social power acquired (not power given over or handed down by others)', and "'sustainability" is the language of the haves rather than the have nots'. The forces pushing in the direction of greater NGO operational effectiveness could indeed result in the global South being seen as, 'a passive recipient of micro projects from a North where lobbying efforts must be concentrated because this is where the important decisions lie'. ${ }^{18}$

The clarity with which Oxfam was able over time to hear the multilingualism of the 'contact zones' was affected by the nature of the organisation's own aid model, its 
institutional distance from the space itself, and its perception of the socio-political dynamics of the specific area. The implicitly anglophone framing of government funding and the claims of 'upward accountability' to donors which went with it (Banks et al., 2015) tended to reinforce aid monolingualism, standardising the diversity of the 'contact zones', and in effect muffling the chorus of languages and voices within it.

\section{Learning from intercultural encounters of aid and development}

The extent to which an agency like Oxfam could learn interculturally from its encounters in the 'contact zones' depended in many ways on the openness and porosity of the organisation's own multiple spaces of activity, the linguistic hospitality it displayed by overtly accepting other ways of naming and enacting aid and development, and the provision of language and translation policies as integral elements in ongoing initiatives to regionalize and globalize.

Describing the multiple spaces of aid and development activities has always been difficult for agencies: Oxfam has used a variety of metaphors over the years to characterise its organisation - Oxfam was a tapestry made up of various threads, ${ }^{19}$ or an amoeba (Whitaker, 1983, p. 30). Nevertheless, a common theme in Oxfam's history was an understanding that there was a 'frontline', ${ }^{20}$ sites of meeting in which 'field staff ${ }^{21}$ have 'contact with partners', and 'face-to-face' encounters with foreign others. ${ }^{22}$ From the beginning, the notion of spending time and developing relationships on the ground was key to Oxfam's self-perception of its working style, a willingness, 'to invest an enormous amount of time in simply talking. ${ }^{23}$ However, as the organisation grew and changed, it became evident that the two worlds of Oxfam - the overseas field, and the headquarters in Oxford - were tending to become more distanced in both organisational and conceptual terms. To begin with, Oxfam employees overseas operated on different contracts from those in headquarters. Expatriate staff were on fixed-term contracts unlike their permanently employed home colleagues, whilst there were even sharper differentials between expatriate and locally employed personnel. ${ }^{24}$ In the mid-1980s, some Human Resources policies, like Health and Safety, omitted any reference to overseas work, ${ }^{25}$ whilst the organisation had, 'no records of locally employed staff in the field. This had come to light recently when one of our Ethiopian staff had "disappeared" and we could not provide very much in the way of details of him'. ${ }^{26}$

Intermediary mechanisms for bringing together extra-UK activity and Oxfam headquarters, learning bridges between the 'field' and Oxfam, traditionally took the form of paper trails, following programmes from project applications to the ongoing and final field reports on the specific activity. Requests for project funding from local communities had generally arrived at Oxfam headquarters written in European languages. In 1973, the Overseas Director, calling it, 'such a simple matter that I hesitate to raise it', mentioned the case of one would-be applicant for funds who had not applied because he was unable to write in English. By 1991, however, it seemed that the institutional language of choice for these applications was still English, with the result that the voice of local applicants was potentially heard by the institution at several removes. ${ }^{27}$ By the early 1990s, it appeared that the huge volume of reports and feedback from the field were, in practice, only rarely consulted by those at Headquarters: 'The information arriving in Oxford in thousands of PASFs (Project Application Summary Forms) remains largely unused. ${ }^{28}$ Thus, 
gaining an institutional understanding of what Oxfam's field programmes were all about presented considerable problems, with the agency itself perceiving in the 1990s a growing gap between 'the overseas programme as understood by the field officers and the interpretation of the programme by the rest of Oxfam', ${ }^{29}$ what was in effect, 'a gulf between policy makers and the reality of our work in the field, rhetoric and reality'. ${ }^{30}$

The growth and sheer geographical range of Oxfam's operations further complicated any attempts to bring intercultural learning from the field into the institution's own learning spaces. From the 1970s to the early 1990s, the number of overseas Oxfam sites mushroomed. In 1991, there were over 40 country and regional offices, and more than 3000 individual grants were processed in one year. ${ }^{31}$ Given the incremental nature of this growth, there were inconsistencies between the work of various country offices: in Chile, a Programme Officer could be dealing with 75 projects, in Ahmedabad with only $2{ }^{32}$ In Latin America, Oxfam operated a regionalised structure, with a single office for six Andean countries, whilst in Africa, there was a 'plethora of small country offices' ${ }^{33}$ These multiple and very different regional and project sites spilled over to an even broader area in the early 1990s when Oxfam came under pressure to work on the ground with other NGO networks, particularly from the South, and to lead regional meetings on behalf of sister Oxfams (Oxam Belgium, Oxfam Quebec, Oxfam America) which might not be represented there. ${ }^{34}$

In this situation, it was little wonder that Field Directors/Officers complained about the pressures they were under in making meaningful contacts with communities. One reported in 1985 that he was supposed to visit 200 projects twice a year as well as dealing with expanding administrative demands coming from Oxford, ${ }^{35}$ and by 1998, there were increasing worries that distances, and the extraordinary growth in project activity were making 'face-to-face opportunities' rare, with a concomitant 'loss of personal relationships to solve problems ... losing contact with partners' ${ }^{36}$

Attempts to bridge the gap between field and headquarters by the creation of intermediary management tiers in the organisation in the 1990s - Regional Managers, or communications specialists - were not entirely successful. Regional Managers based in Oxford had been expected to facilitate a 'two-way process ${ }^{37}$ of listening between the field and Oxfam's Headquarters, and crucially to, 'represent the views and concerns of field staff within Oxfam debates'. ${ }^{38}$ Because of the variety of overseas arrangements however, Regional Managers found that their actual relationships with Field Staff varied enormously from the Latin American case where the overseas office took the major initiative, leaving little room for the Regional Manager in Oxford, to the African experience where much smaller field offices permitted some independent role for the Oxford-based manager to play. Without any discrete budgetary responsibility, these intermediaries found themselves sandwiched uncomfortably between the field and Oxford policy-making: 'They felt "at the neck of an hour glass". 39 So difficult was it to actually bring overseas stories into Oxfam's headquarters that the communications/campaigns unit in Oxford occasionally created their own fictitious frontline voices, using information gathered from various sources, in effect bypassing both regional desks and overseas specialists. ${ }^{40}$

Despite these organisational difficulties, however, traces of the transnational, of the foreignness of Oxfam's overseas encounters, entered both linguistically and culturally into its institutional debates, signs of some measure of linguistic hospitality. One of the clearest and most striking examples of this, which largely predated the 'accountability turn' of 
the 1990s, was the alternative language of development spoken in Latin America and Brazil from the 1970s onwards. Oxfam's commitment in Latin America and Brazil at a time of tremendous religious and social ferment, and the lively engagement of its Sppanish-speaking and Portuguese-speaking representatives, brought a strikingly different foreign development lexicon into the centre of Oxfam's own discussions and practices. During this period, Oxfam was said to be harmonising its thinking with progressive Brazilian and Latin American thinkers, like Paulo Freire, and Gustavo Gutiérrez, ${ }^{41}$ and vocabulary like 'concientización' in Spanish or 'conscientizaçăo' in Portuguese was visible and widely used in committees and reports. Senior Oxfam officers involved in Spanish-language debates on development regularly highlighted the importance of Spanish terms to describe the processes underway: 'cooperación popular', 'informalización' (of third world economies), and 'organización de base'. ${ }^{42}$ This foreign lexicon was then transferred to Oxfam's activities in other continents. Thus, for example, Field Directors in Asia were provided with helpful crib sheets: 'In case you are as confused as some of us here have been by some of the ideas coming from Latin America, I am enclosing a copy of a brief and fairly succinct explanation of conscientization ... ${ }^{43}$ Oxfam of course was not alone in this. The influence of Latin American formulations of aid and development were evident too in other agencies in the mid-1980s, exported by the WCC to Zaire, for example, and translated into French: 'conscientisation', 'sensibilisation' ${ }^{44}$

In the case of ex-colonial countries where English was still an official language, it took rather longer for the mutuality of aid relationships to be visibly translated into Oxfam's discussions and decision-making. This process was spurred on by the agency's need to find conduits of aid which were manifestly independent of local governments keen to take control of foreign funding, and of overt expatriate interference. In Malawi, for example, to avoid dealing with the repressive Hastings Banda government, Oxfam worked with the University of Malawi Centre for Social Research, under the leadership of Louis Msukwa, ${ }^{45}$ 'about the most knowledgeable Malawian there is in social development issues'. ${ }^{46}$ Msukwa also provided Oxfam with its 1986 review of the country. ${ }^{47}$ His Mulanje project, involving six Malawian researchers who stayed in villages for four months, specifically included a training programme to help local researchers explain the project to their communities in Chichewa. This initiative in effect employed local languages as a means of sharing development responsibility: 'a process which enables people to take more control of their lives' (Trivedy, 1990, p. vii). In the wake of these changes, Malawian languages and concepts began to appear within Oxfam institutional documents in the 1990s. Future programme plans specifically noted the range of languages spoken by the majority of Malawians, as opposed to the small number of people who spoke English, ${ }^{48}$ and reports on Oxfam activity included quotations in Chichewa - 'Mutu umodzi susenza denga' ('one head cannot carry a roof) - together with discussions of Malawian/Chichewa formulations of leadership. ${ }^{49}$

Balancing the pressures of a now sizeable transnational organisation which aspired to encourage diversity, with the perceived need to maintain one overall vision, became a major challenge. In 1986, when Oxfam embarked on an institutional programme of 'Knowledge of Oxfam' courses outside the UK, feedback suggested that more linguistic openness was needed across the whole organisation: 'Inadequacies of English as the exclusive medium are often a barrier to effective communication. ${ }^{50}$ The dilemma faced by 
Oxfam, which was linguistic as much as institutional, was how to foster narrative plurality and local autonomy within a growing global organisation:

We would expect each region to have its own flavour and distinctive configuration of programme/ skills/ size/ spread/etc. However, it is essential to the success of Oxfam's Globalisation project ... that the staff of every Region feel and behave primarily as part of a larger whole, as part of a global Oxfam, rather than primarily as part of a local Oxfam ... ${ }^{51}$

Already, however, in 1993, overseas Oxfam staff were raising issues around: 'the multi-cultural nature of Oxfam and steps to make Oxfam a more multicultural organisation'. ${ }^{52}$ Internally too, there were concerns about how to develop what Oxfam called, 'Working cross-culturally', by which it meant understanding and respecting different cultures within the institution, rather than considering intercultural connections, concentrating on identifying, 'organisational changes that need to be implemented in order that Oxfam works effectively and equitably in cross-cultural contexts'. ${ }^{53}$

In 1990, the very process of consulting Oxfam staff throughout the world on the direction that a globalised and regionalised Oxfam should be taking revealed how difficult it was to learn from voices which were not anglophone within the overall institutional framework. To begin with, there was a major cultural problem in assuming that Westernderived concepts of strategic planning could be uncritically translated into a variety of different regional contexts. Consultative documents for Oxfam's Strategic Review were not accessible to many of those working with Oxfam worldwide. Whilst some papers were translated into French and Spanish, others were not: 'many teams did not work in English, and this meant translating the draft plans into English, translating comments on the draft, re-drafting in the original language, working on the document, and then re-translating it'. Given how complex much of the material was, ownership of the translation tended to rest with senior staff whose first language was English. ${ }^{54}$ Whilst consultative staff workshops might argue that Oxfam was a multilingual organisation with English as the primary language, there was no shared institutional idea as to what this implied in language/translation policy terms. ${ }^{55}$ In general, the organisational approach to linguistic translation tended to be ad hoc. When, for example, Oxfam considered in 1986 adopting a policy to translate all its books into French and Spanish, with the potential addition of Portuguese and Arabic, the cost was deemed prohibitive. ${ }^{56}$ By the time the organisation was preparing for its major restructuring and regionalisation exercise ('Globalised and regionalised Oxfam') in the late 1990s, it was evident that there was still no formal translation policy, but rather a variety of practices funded by very different budgets, translating documents mainly into French, Spanish, Portuguese, Arabic, and English, with 'grey' publications for local/national use often translated into local or regional languages. ${ }^{57}$ Given that corporate documents, books, journals, press statements, and internal documents now had to be shared across the whole transnational organisation, a recognition grew in 1998 that some coherent language policy had to be developed: 'It is clear ... . that translation (including interpretation services) is a key Strategic Area for Oxfam's communications in a regionalised and globalized Oxfam. ${ }^{58}$

The linguistic implications of an aid and development agency learning interculturally and multilingually were thus evident by the early 1990s:

The issues of choosing which language to work in and coping with the lack of professional translators have dogged Oxfam for years. While it is a multi-cultural organisation, English 
is still the dominant medium, and many field staff are excluded from key debates because they lack proficiency in English. Oxfam has never been able to decide whether to use English and recruit and train staff in English, or whether to be multi-lingual and invest in translation resources, which would be costly. The problems and conflicts of language come up in every major exercise undertaken by the organisation, and yet the issue continues to be unresolved. (Wallace \& Burden, 1994, p. 28)

The problem of learning institutionally across multiple and wide sites of engagement was a real issue for Oxfam in the 'contact zones' of aid and development. Linguistic hospitality, naming the 'foreign other' in their own languages and terms in debates and policy discussions, depended on an institutional willingness to cede some measure of control of their initiatives and programmes. With the 1990s' push to globalise and regionalise, Oxfam grappled with how it would engage its transnational staff in some terms of linguistic equity.

\section{Conclusions}

The current Deputy Chief Executive of OxfamGB has argued that the recent One Oxfam internationalisation process which will bring 17 Oxfam affiliates together all over the world now provides real opportunities for institutional change and learning (Lawrence, 2015). From the historical evidence of Oxfam's previous 60-year engagement, it seems that any future initiatives to make the multilingualism of the 'contact zones' of aid and development more audible will need to take account of the precise organisational model of the agency, of its own languages and histories, and of its perceptions of local interlocutors. The example of Oxfam suggests that the ways in which institutions historically identified the voices to whom they listened were closely related to the politico-social dynamics of the particular spaces of their aid and development activities. The power of the donor government provided both a framework of implicit historic assumptions about the English language, and a largely unquestioned practice of feedback and evaluation, rooted linguistically as much as conceptually in anglophone models of management and strategic thinking. What emerges from this initial study of the 'contact zones' of aid and development is the complexity of an intercultural and multilingual field constituted by the institution's own organisational structures and histories, as well as by the politico-social dynamics of the individual site of encounter, and the economic power of government forces which had the wherewithal to sponsor activity, or refuse funding.

The ways in which an agency like Oxfam learned interculturally from its 'contact zones' depended crucially on the porosity of its multiple and overlapping fields of activity. Mechanisms which provided bridges between the local and the global, and facilitated mutual understanding and change, might be located at each stage of project application and feedback, but arguably depended for their effectiveness on the organisation's ability to maintain and prize personal contacts and the learning which these might bring. The linguistic hospitality which Oxfam displayed was exhibited in the visible traces of the transnational within its own discussions and reports, recognising the 'foreign others' by naming their identities and practices in their own languages, a particularly suggestive indication of the degree to which the interculturality of the transnational was a two-way learning process. Inevitably, the mutuality of transfer between the local and the global, the possibility of this two-way learning process, implied the adoption of language policies and 
practices which both respected 'the other', and supported the sort of linguistic hospitality to which Ricoeur alluded.

These conclusions on the factors which shape the intercultural spaces of development have lessons too for educational groups which intervene in areas of emergency and pain, encouraging them to be aware of the ways in which their own organisational structures and histories, the politico-social dynamics of the site, and the economic forces to which they are subject condition the relationships which they are likely to be able to build within the contact zones of education. Ensuring that there are institutional bridges between the local and the global, and prizing personal contacts as a means of promoting new thinking and organisational change could arguably stimulate educational perspectives which are imaginative and flexible. Above all, educational intervention in these contexts of change and danger requires real organisational commitment to a two-way learning process which can foster linguistic hospitality of the sort we noted in Oxfam's own history.

There is a sense in which 'contact zones' reimagined in this way as multilingual and intercultural may help to reposition the spaces of education, as well as those of aid and development, challenging their traditional framings as zones which have been purposefully constructed in order to enable educators and students, and aid givers and recipients to meet together pragmatically so as to accomplish quantifiably effective work. Rather, we might begin to imagine them as contingent sites of inevitably unsatisfactory and messy physical human encounters which are, like all human endeavours, troubling and unfinishable. In this imagining, we will all - educationalists, activists, intercultural scholars and development specialists alike - find ourselves being less measurably effective, becoming used to the incomplete, accepting that we will be living in discomfort. As the poem 'Counting guts' (quoted in Eyben, Guijt, Roche, \& Shutt, 2015, p. xiii) graphically puts it:

How does one persuade the pains of identity

to fit obediently into assessment charts?

The struggle for change

Tears your stomach apart

Your intestines fall at your feet.

Still, you have to pick them up and count them.

Counting guts is not the problem ...

How does one turn them into a stringed quartet?

\section{Notes}

1. Christian Aid Archive, SOAS, CA2/D/14/9, 14 August 1974.

2. Bodleian Library Oxford (hereafter MS Oxfam), PRG 1/1/3 Overseas Aid Committee, 18 December 1967.

3. MS Oxfam PRG 1/13/1 Vacant appointments in Oxfam, 11 January 1983;

4. MS Oxfam PRG 2/2/1 Bennett to Field Directors, 15 January 1971.

5. MS Oxfam PRG 1/13/2 Area Coordinators Meeting, 10 April 1986.

6. MS Oxfam PRG 1/13/7 Paper John Gwynne, 25 July 1990.

7. MS Oxfam PRG 1/5/2 Field Committee for Latin America, Andean Annual Report, November 1972-November 1973; MS Oxfam PRG 1/5/2 Field Committee for Latin America, report Charles Skinner, September 1987.

8. MS Oxfam PRG 3/4/16 Andes reports, Annual report, 1987-88.

9. MS Oxfam PRG 7/19 OxfamGB and Ireland, Mulanje Programme Plan, 1996-7. 
10. MS Oxfam PRG 7/19 Malawi country reports, Mulanje project, 17 April 1991; MS Oxfam PRG 3/5/11, Comments on country report from Louis Msukwa, 10-18 June 1985; MS Oxfam PRG 2/3/1/11 Malawi visit 24 November 1997, Magrath to Bryer.

11. MS Oxfam PRG 3/5/24 Tour Report, B.and D. Huey, March 1995; MS Oxfam PRG 1/5/2 Annual Report Andean Region, 1974-5; MS Oxfam PRG 3/4/16 Andes Annual Report, 1988-9.

12. I am grateful to Dr Angela Crack for this analysis and supporting references.

13. MS Oxfam PRG 1/1/1 Note on FAO, 27 March 1961.

14. MS Oxfam PRG 2/1/11 Overseas Division, Strategic Plan, January 1993.

15. MS Oxfam PRG 1/13/7 Frances Rubin, June 1991.

16. MS Oxfam PRG 2/1/1 Overseas Division, 'Focus and Impact in the Overseas Programme', 1995-1997, paper 7.

17. MS Oxfam PRG 1/13/2 Area Coordinators, Report of the Working Group on staffing needs and roles overseas, January 1985.

18. MS Oxfam PRG 1/11/1 Africa Management Team Paper, Richard Moseley-Williams, 27 November 1992.

19. MS Oxfam PRG 2/3/8/27 Bryer to Judd, 8 November 1990.

20. MS Oxfam PRG1/11/1, 23 September 1992.

21. MS Oxfam PRG 1/1/3, 23 October 1973.

22. MS Oxfam PRG 2/3/8/31, October 1998.

23. MS Oxfam PRG 2/3/1/11 Malawi visit 24 November 1997, note Magrath to Bryer.

24. MS Oxfam PRG 1/13/3 'To have and to hold', Discussion paper, 17 September 1986.

25. MS Oxfam PRG 1/13/2 Area Coordinators, 6 May 1986.

26. MS Oxfam Area Coordinators, 24 February 1986.

27. MS Oxfam PRG 1/13/7 Frances Rubin, Planning and Evaluation Unit, June 1991.

28. MS Oxfam PRG 1/12/1 Overseas Committee, Programme framework approach, 29 January 1993.

29. MS Oxfam PRG 1/11/1 Africa Management Team, December 1992.

30. MS Oxfam PRG 1/11/1 Africa Management Team, Review of Regional Managers Meeting, 14 December 1992.

31. MS Oxfam PRG 2/1/1 Overseas Division, Strategic Plan, January 1993.

32. MS Oxfam PRG 1/13/7 Frances Rubin, Planning and Evaluation Unit, 1991.

33. MS Oxfam PRG 2/1/1 Overseas Division February 1989.

34. MS Oxfam PRG 1/12/1 Overseas Committee, 8 April 1992; PRG 1/13/7 McCartney to Bryer 18 July 1990.

35. MS Oxfam PRG 1/13/7 Barry Underwood, 22 April 1985.

36. MS Oxfam PRG 2/3/8/31 Think Global Workshop, October 1998.

37. MS Oxfam PRG 1/11/1 Africa Management Team, 6 March 1993.

38. MS Oxfam PRG 1/11/1 Africa Management Team, Regional Managers' Awayday, December 1992.

39. MS Oxfam PRG 1/11/1 Africa Management Team, Africa Away day, 17 March 1993.

40. MS Oxfam PRG 1/11/1 Africa Management Team, 1 October 1992.

41. MS Oxfam PRG 1/5/2 Field Committee for Latin America, 10 October 1973.

42. MS Oxfam PRG 3/4/16 Andes reports, Annual report 1987-88.

43. MS Oxfam PRG 2/2/1 Harris to Asian Field Directors, 26 November 1973.

44. Christian Aid Archive, SOAS, CA5/A/370B, Eglise du Christ au Zaire, 6-9 October 1986.

45. MS Oxfam PRG 7/19 Mulanje project, 17 April 1991.

46. MS Oxfam PRG 3/5/11 Visit to University of Malawi, 11 December 1984.

47. MS Oxfam PRG 16/7/86 Malawi country review, 16 July 1986.

48. MS Oxfam PRG 7/19 OxfamGB \& Ireland Mulanje Programme Plan, 1996-1997.

49. MS Oxfam PRG 3/8/10 Malawi Strategic Plan 1996-1999, 26 November 1996, comments 5 March 1998.

50. MS Oxfam PRG 1/13/3 Report, 24 September 1986.

51. MS Oxfam PRG 2/1/1 International Division Strategic Plan, 1999-2004. 
52. MS Oxfam PRG 1/12/1 Asia Regional meeting, 23 March 1993.

53. MS Oxfam PRG 1/13/7, 6 August 1990.

54. MS Oxfam PRG1/13/7, Planning and Evaluation Unit, June 1991.

55. MS Oxfam PRG 2/3/8/31 Think Global Workshop, October 1998.

56. MS Oxfam PRG 1/13/3 Area Coordinators Meeting, 15 December 1986.

57. MS Oxfam PRG 2/3/8/31 'Think Global' Workshop, October 1998.

58. MS Oxfam PRG 2/3/8/31 'Think Global' Workshop, October 1998.

\section{Acknowledgements}

I acknowledge with gratitude the support of the AHRC, and the comments and suggestions of Dr Angela Crack and Dr Wine Tesseur.

\section{Disclosure statement}

No potential conflict of interest was reported by the author.

\section{Funding}

This project was funded by the AHRC [AH/M006808/1].

\section{Notes on contributor}

Hilary Footitt is a Senior Research Fellow in the Department of Modern Languages and European Studies at the University of Reading, UK. She has written widely on language policies and practices in conflict zones. She is currently PI for the AHRC funded project, 'The Listening Zones of NGOs: languages and cultural knowledge in development programmes' (www.reading.ac.uk/listeningzones-ngos).

\section{References}

Abu-Sada, C. (Ed.). (2012). In the eyes of others. How people in crises perceive humanitarian aid. Montreal: McGill Queen's University Press.

Anderson, M., Brown, D., \& Jean, I. (2012). Time to listen. Hearing people on the receiving end of international aid. Cambridge, MA: CDA Collaborative Learning Projects.

Banks, N., Hulme, D., \& Edwards, M. (2015). NGOs, states, and donors revisited: Still too close for comfort? World Development, 66, 707-718.

Bond. (2015). Fast forward: The changing role of UK-based INGOs. London: Bond.

Coleman, H. (2010). The English language in development. London: British Council.

Cornwall, A., \& Eade, D. (2010). Deconstructing development discourse. Buzzwords and fuzzwords. Rugby: Practical Action Publishing with OxfamGB.

Davey, E., \& Scriven, K. (2015). Humanitarian aid in the archives: Introduction. Disasters, 39(S2), s113-s128.

DDD. (2014). Doing development differently. Retrieved May 12, 2017, from http:// doingdevelopmentdifferently.com/

Dichter, T. (1999). Actionaid taking stock summary report. London: ActionAid.

Dijkzeul, D. (2008). Transnational humanitarian NGOs? A progress report. In L. Pries (Ed.), Rethinking transnationalism. The meso-link (pp. 80-103). Abingdon: Routledge.

Djité, P. (1993). Language and development in Africa. International Journal of the Sociology of Language, 100/101, 149-166.

Djité, P. (2008). The sociolinguistics of development in Africa. Clevedon: Multilingual Matters. 
Eyben, R., Guijt, I., Roche, C., \& Shutt, C. (2015). The politics of evidence and results in international development. Rugby: Practical Action.

Green, D. (2015). How can big aid organizations thrive in uncertainty and become fit for the future? A summary of my new paper. Retrieved May 12, 2017, from, http://oxfamblogs.org/fp2p/howcan-big-aid-organisations-become-fit-for-the-future-a-summary-of-my-new-paper

Holmes, P. (2014). Intercultural dialogue: Challenges to theory, practice and research. Language and Intercultural Communication, 14(1), 1-6.

ICRC. (2009). Our world, views from the field. Retrieved January 6, 2017, from http://www.icrc.org/ eng/assets/files/other/summary-report.pdf

Khagram, S., \& Levitt, P. (2008). Constructing transnational studies. In L. Pries (Ed.), Rethinking transnationalism. The meso-link (pp. 21-39). Abingdon: Routledge.

Lawrence, P. (2015). Oxfam Big Cheese responds to my paper on whether INGOs are 'fit for the future'. Retrieved May 12, 2017, from http://oxfamblogs.org/fp2p/Oxfam-big-cheese-respondsto-my-paper-on-whether-ingos-are-fit-for-the-future-2/

Marais, K. (2014). Translation theory and development studies: A complexity theory approach. New York, NY: Routledge.

Massey, D. (2005). For space. London: Sage.

Najar, U. (2016). 'The intercultural field': Interrogating context in intercultural education. Language and Intercultural Communication, 16(2), 148-163.

Oxfam Handbook. (1995). Handbook of development and relief (Vol. 1). Oxford: Oxfam.

Phipps, A. (2014). 'They are bombing now': 'Intercultural dialogue' in times of conflict. Language and International Communication, 14(1), 108-124.

Prat, B., \& Boyden, J. (1985). The field directors' handbook. An Oxfam manual for development workers. Oxford: For Oxfam by OUP.

Pratt, M.-L. (2008). Imperial eyes. Travel writing and transculturation. Abingdon: Routledge.

Pries, L. (2008). The transnational societal spaces: Which units of analysis, reference and measurements? In L. Pries (Ed.), Rethinking transnationalism. The meso-link (pp. 1-20). Abingdon: Routledge.

Ricoeur, P. (2006). On translation (E. Brennan, Trans.). London: Routledge.

Robinson, C. (1996). Language use in rural development. An African perspective. Berlin: Mouton de Gruyter.

SDG 10. UN sustainable development goals. Retrieved May 12, 2017, from http://www.un.org/ sustainabledevelopment/sustainable-development-goals/

Smirl, L. (2015). Spaces of aid. How cars, compounds and hotels shape humanitarianism. London: Zed Books.

Taylor, J. (2010). Translating hospitality: Paul Ricoeur's ethics of translation. The New Arcadia Review. Retrieved August 23, 2016, from http://omc.bc.edu/newarcadiacontent/ translatingHospitality_edited.html

Trivedy, R. (1990). Action research in Southern Malawi (Oxfam Research Paper). Oxford: Oxfam. Wallace, T., \& Burden, T. (1994). Strategic planning review (Oxfam Research Paper 10). Oxford: Oxfam.

Whitaker, B. (1983). A bridge of people. A personal view of Oxfam's first forty years. London: Heinemann. 